\title{
11. 当院におけるネロアナライザーによるX線出力品質管理の一考察
}

\author{
主正佼成会附属佼成病院放射線科 ○渡辺雅弘・高山热・池の上和子・酒井久想
}

(纥じめに)

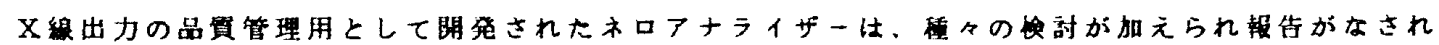

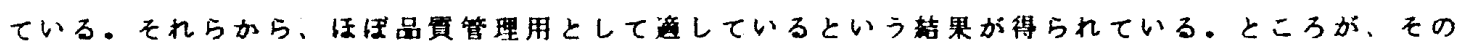

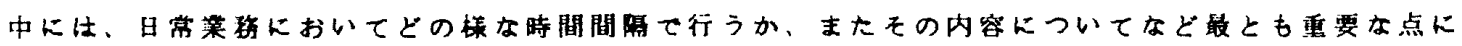

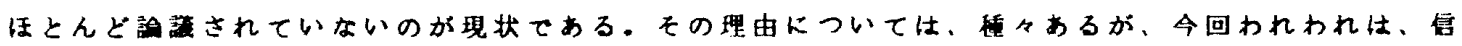

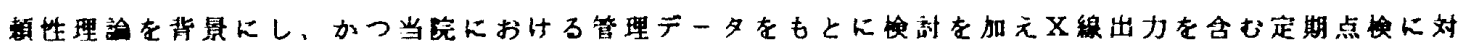

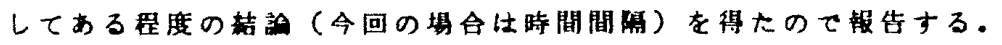

(方法)

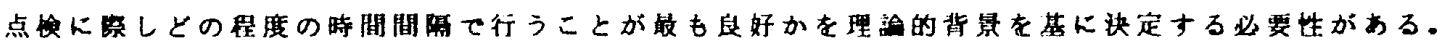

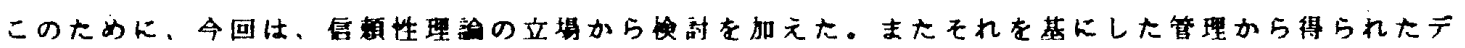
一タを舒した。

(菭果及ひ拮敦)

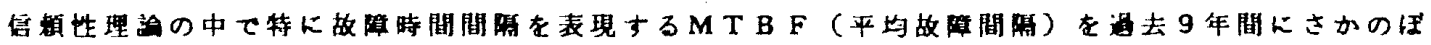

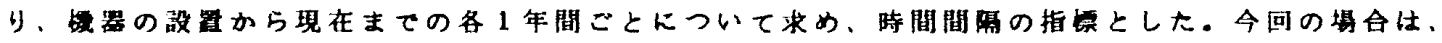

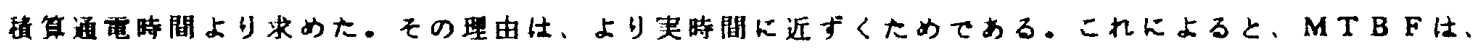
バスタブ曲悢の部分いわゆる安定期においては、150時間程度といえる。MTBFにおいては、

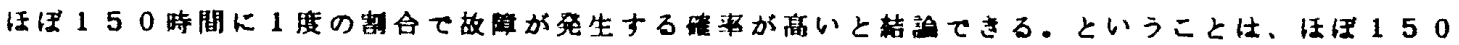

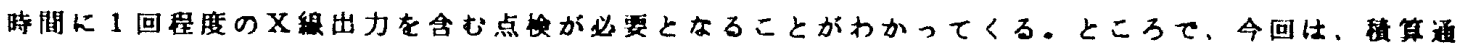

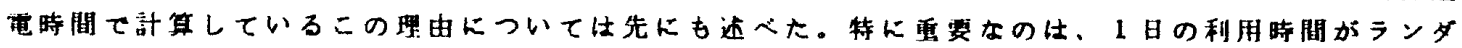
ムでり特定できいことが大きな理由でる。そうなると、時閒閒陑が 150 時間ことというのは

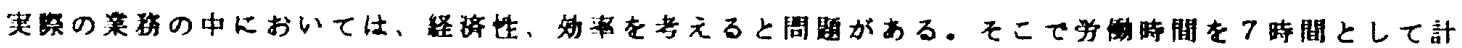

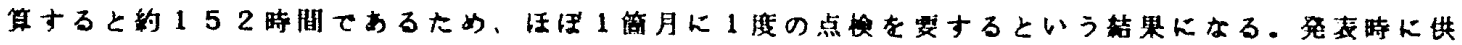

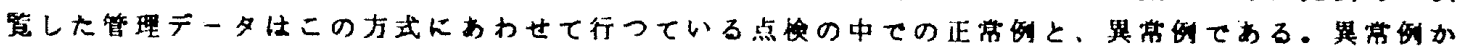

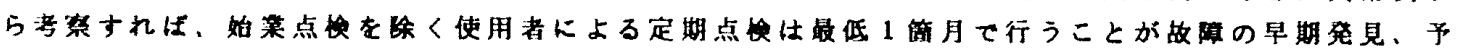
防に対して必要である。なお、発表時においてわかりやすくするために1例のみを表示した。 (考察)

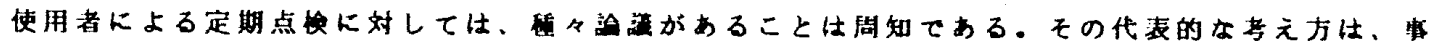

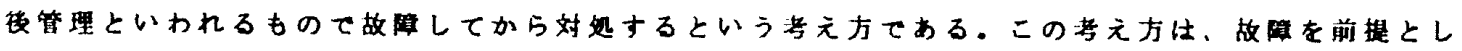

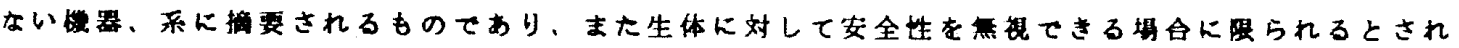

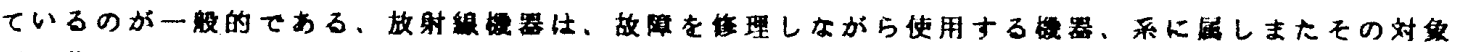

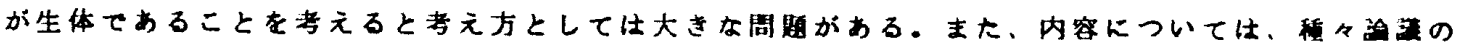
分かれるところだが、容易であることを念㖽に、安全性と协事性が望まれるのはいうまてもない。

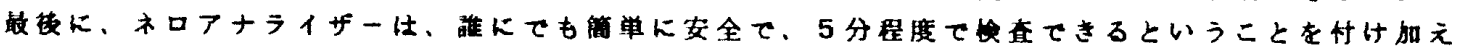
ておく.

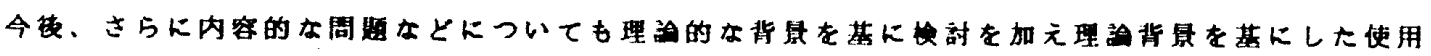
者による芫期点の站立目指したいと考元る。 